\title{
ANALISIS PENYERAPAN TENAGA KERJA SEKTOR INDUSTRI DI PROVINSI JAWA TENGAH
}

\author{
Tanti Siti Rochmani ${ }^{1}$, Yunastiti Purwaningsih ${ }^{2}$, Agustinus Suryantoro $^{2}$ \\ ${ }^{1}$ BPS Kota Surakarta, Indonesia \\ ${ }^{2,3}$ Fakultas Ekonomi dan Bisnis Universitas Sebelas Maret \\ Email: tsitirochmani@yahoo.com,yst_stm@yahoo.com, \\ tinus_surya@yahoo.com
}

\begin{abstract}
The purpose of this study was to analyze the factors affecting employment in the industrial sector of Central Java province. Research backdrop that aspects of employment is a fundamental aspect in the economy. The economy is growing through the process of industrialization, should be able to absorb a lot of labor. With more and more workers absorbed there will be an increase in welfare of the population. This study is an analysis of secondary data such as time series data tahun2010-2014. The analysis technique used is the panel data regression. The results showed the rate of economic growth and the minimum wage Regency / City positive effect on employment, while the number of un $t$ of industrial enterprises have no effect on employment in the industrial sector of Central Java province.
\end{abstract}

Keywords: employment, economic growth, minimum wage, industrial, Central Java JEL Classification: E23, J61

\section{PENDAHULUAN}

Proses pembangunan seringkali dikaitkan dengan proses industrialisasi. Proses industrialisasi merupakan satu jalur kegiatan untuk meningkatkan kesejahteraan rakyat dalam arti tingkat hidup yang lebih maju maupun taraf hidup yang lebih bermutu. Arsyad (2010) menyatakan bahwa pembangunan industri merupakan suatu fungsi dari tujuan pokok kesejahteraan rakyat, bukan merupakan kegiatan yang mandiri untuk hanya sekedar mencapai fisik saja. Sektor industri diyakini sebagai sektor yang dapat memimpin sektorsektor lain dalam sebuah perekonomian menuju kemajuan (Dumairy, 1996). Produk-produk industrial memiliki "dasar tukar" (term of trade) yang tinggi atau lebih mengun- tungkan, serta menciptakan nilai tambah yang besar dibanding produkproduk sektor lain. Salah satu tujuan penting dalam pembangunan ekonomi melalui proses industrialisasi adalah penyediaan lapangan kerja yang cukup untuk mengejar pertambahan angkatan kerja yang pertumbuhannya lebih cepat dari pertumbuhan kesempatan kerja. Hal ini menunjukkan bahwa salah satu permasalahan utama yang dihadapi sampai dengan saat ini, dan masih belum teratasi adalah relatif masih tingginya angka pengangguran.

Jawa Tengah merupakan provinsi dengan nilai PDRB terbesar keempat se-Indonesia. Selama periode tahun 2009-2013 kinerja perekonomian di Provinsi Jawa Tengah menunjukkan kondisi yang cukup baik, dilihat dari laju pertumbuhan ekonomi. Data Bappenas (2014) menunjukkan 
laju pertumbuhan ekonomi Jawa Tengah tahun 2009 lebih tinggi dibanding laju pertumbuhan ekonomi nasional, dan pada tahun 2013 menunjukkan angka laju pertumbuhan ekonomi yang hampir sama (gambar 1).

Gambar 1.

Laju Pertumbuhan Ekonomi Jawa Tengah dan Nasional (2009-2013)

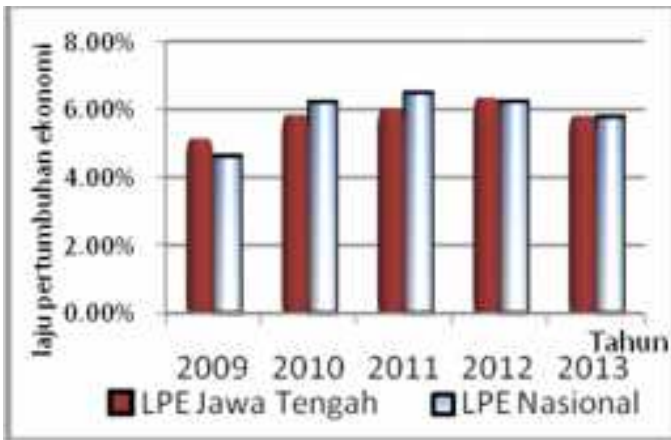

Sumber: BPS Provinsi Jawa Tengah, 2015.

Struktur perekonomian Provinsi Jawa Tengah tahun 2013 didominasi sektor industri pengolahan, perdagangan, dan pertanian. Sektor industri pengolahan memberikan kontribusi terbesar terhadap pembentukan nilai PDRB, diikuti sektor perdagangan dan sektor pertanian (Bappenas, 2014). Dengan berkembangnya sektor industri pengolahan dan perdagangan, diharapkan mampu menyerap tenaga kerja yang ada di Jawa Tengah. Berdasar kondisi tersebut, maka penelitian ini mengkaji faktor yang berpengaruh terhadap penyerapan tenaga kerja di Provinsi Jawa Tengah.

\section{PERUMUSAN MASALAH}

Pertumbuhan ekonomi mencerminkan kegiatan produksi, dimana kegiatan produksi memerlukan faktor produksi, di antaranya tenaga kerja. Kegiatan produksi dilakukan oleh para pengusaha, utamanya yang bergerak di bidang industri, sehingga banyaknya industri akan berpengaruh terhadap penyerapan tenaga kerja. Sementara itu upah yang berlaku, yaitu upah minimum yang ditetapkan setiap tahunnya oleh bupati dan gubernur akan berdampak pada jumlah tenaga kerja yang dipekerjakan oleh perusahaan. Berdasar uraian tersebut, maka permasalahan penelitian ini adalah :

Bagaimana pengaruh pertumbuhan ekonomi, upah minimum Kabupaten/kota (UMK) dan jumlah unit usaha industri terhadap penyerapan tenaga kerja di Jawa Tengah?

\section{TINJAUAN PUSTAKA DAN HIPOTESIS}

Perkembangan roda perekonomian suatu daerah secara cepat mencerminkan aktivitas produksi yang tinggi. Kapasitas produksi yang tinggi membutuhkan tingginya faktor produksi, di antaranya adalah tenaga kerja. Dengan demikian dapat dinyatakan bahwa pertumbuhan ekonomi yang meningkat, akan menaikkan penyerapan tenaga kerja (Simanjuntak, 2001).

Sementara itu, hubungan antara upah dan penyerapan tenaga kerja dapat digambarkan bahwa semakin tinggi tingkat upah akan berdampak pada meningkatnya biaya produksi, dan akibat selanjutnya perusahaan akan melakukan efisiensi dengan mengurangi tenaga kerja yang dipekerjakan (Simanjuntak, 2001). Kondisi ini mengakibatkan rendahnya tingkat kesempatan kerja. Dengan pernyataan lain, upah berpengaruh negatif terhadap penyerapan tenaga kerja. Jumlah unit usaha industri berkaitan erat dengan penyerapan tenaga kerja. Semakin banyak jumlah unit usaha, maka semakin banyak pula jumlah tenaga kerja yang diperlukan dalam suatu industri (Karib, 2012). Dapat disimpulkan bahwa jumlah unit usaha industri mempunyai pengaruh 
positif terhadap penyerapan tenaga kerja.

Penelitian terdahulu mengenai penyerapan tenaga kerja sektor industri telah dilakukan banyak peneliti. Indradewa (2015) meneliti tentang pengaruh inflasi, Produk Domestik Regional Bruto (PDRB) dan upah minimum terhadap penyerapan tenaga kerja di Provinsi Bali periode tahun 1994-2013. Teknik analisis yang digunakan adalah regresi linear berganda. Hasil penelitian menunjukkan bahwa PDRB dan upah minimum berpengaruh terhadap penyerapan tenaga kerja, sedangkan inflasi tidak berpengaruh terhadap penyerapan tenaga kerja. Munasriah (2015) meneliti pengaruh jumlah unit usaha dan investasi terhadap penyerapan tenaga kerja pada industri kecil di kabupaten Wajo Sulawesi Selatan dengan metode regresi two stage least squares (2SLS). Hasil penelitian menunjukkan bahwa jumlah unit usaha dan investasi berpengaruh positif terhadap penyerapan tenaga kerja pada industri kecil.

Greer, Castrejon \& Lee (2014) meneliti hubungan antara upah minimum dan tingkat pengangguran dengan menggunakan metode analisis regresi sederhana. Penelitian ini menggunakan data negara-negara dengan basis di Amerika Serikat pada tahun 2002 sampai 2012. Hasil penelitian menunjukkan upah minimum memiliki dampak yang signifikan terhadap pengangguran ketika ekonomi tidak stabil, yaitu selama resesi dan pascaresesi, bahwa peningkatan upah minimum meningkatkan pengangguran. Sobita \& Saputra (2014) meneliti pengaruh PDRB riil, upah riil, harga modal bidang pertanian, dan Indeks Harga Implisit terhadap Penyerapan Tenaga Kerja di Provinsi Lampung. Analisis yang diguanakan aalah regresi data panel. Hasil pene- litian menunjukkan bahwa PDRB riil dan harga modal di bidang pertanian berpengaruh positif terhadap penyerapan tenaga kerja, upah riil berpengaruh negatif terhadap penyerapan tenaga kerja.

Yunani \& Mursinto (2014) meneliti pertumbuhan ekonomi dan lapangan kerja serta kesejahteraan sosial di kabupaten/kota Kalimantan Selatan dengan menggunakan metode analisis jalur (path analisis). Hasil penelitian menunjukkan pertumbuhan ekonomi secara signifikan mempengaruhi lapangan kerja, dan bekerja mempengaruhi kesejahteraan masyarakat. Tambunsaribu (2013) meneliti pengaruh produktivitas tenaga kerja, upah riil dan pertumbuhan ekonomi di pasar tenaga kerja Provinsi Jawa Tengah. Teknik analisis yang digunakan regresi berganda. Hasil penelitian ini menunjukkan bahwa produktivitas tenaga kerja berpengaruh negatif terhadap penyerapan tenaga kerja, upah riil dan pertumbuhan ekonomi berpengaruh positif terhadap penyerapan tenaga kerja.

Saputri \& Rejekiningsih (2008) menganalisis faktor yang berpengaruh terhadap penyerapan tenaga kerja di kota Salatiga dengan menggunakan metode analisis regresi berganda. Hasil penelitian menunjukkan bahwa upah memiliki pengaruh positif terhadap penyerapan tenaga kerja, produktivitas tenaga kerja memiliki pengaruh negatif terhadap penyerapan tenaga kerja di Kota Salatiga. Zamrowi (2007) menganalisis penyerapan tenaga kerja pada industri kecil mebel di kota Semarang dengan menggunakan metode analisis regresi berganda. Hasil penelitian menunjukkan bahwa variabel upah, produktivitas modal dan non upah berpengaruh terhadap penyerapan tenaga kerja .

Dari uraian tentang kajian teoritis dan empiris tersebut, penelitian ini 
mengambil variabel laju pertumbuhan ekonomi, upah minimum dan jumlah unit industri, sebagai variabel yang mempengaruhi penyerapan tenaga kerja di provinsi Jawa Tengah. Variabel laju pertumbuhan ekonomi sebagai variabel yang mempengaruhi penyerapan tenaga kerja digunakan oleh Indradewa (2015), Miar (2014), dan Sobita \& Saputra (2014). Variabel upah minimum sebagai variabel yang mempengaruhi penyerapan tenaga kerja digunakan oleh Indradewa (2015), Sobita \& Saputra (2014), Tambunsaribu (2013), Saputri \& Rejekiningsih (2008), dan Zamrowi (2007). Selanjutnya variabel upah minimum dihubungkan dengan pengangguran dilakukan oleh Greer, Castrejon \& Lee (2014). Variabel jumlah unit usaha industri sebagai variabel yang mempengaruhi penyerapan tenaga kerja digunakan oleh Munasriah (2015).

\section{METODE PENELITIAN}

Penelitian ini merupakan analisis data sekunder mengenai pengaruh laju pertumbuhan ekonomi, upah minimum Kabupaten/kota (UMK) dan jumlah unit usaha industri terhadap penyerapan tenaga kerja sektor industri di Provinsi Jawa Tengah. Data yang digunakan adalah data panel yang meliputi 35 kabupaten/kota di seluruh wilayah Provinsi Jawa Tengah dengan periode waktu lima tahun, dari tahun 2010 sampai dengan 2014. Data bersumber dari BPS Jawa Tengah.

Teknik analisis yang digunakan adalah regresi data panel dengan model persamaan regresi sebagai berikut :

$\mathrm{TK}_{\mathrm{it}}=\boldsymbol{\beta}_{0}+\boldsymbol{\beta}_{1} \mathrm{LPE}_{\mathrm{it}}+\boldsymbol{\beta}_{2} \mathrm{UMK}_{\mathrm{it}}+\boldsymbol{\beta}_{3} \mathrm{UUI}_{\mathrm{it}}+\varepsilon_{\mathrm{it}}$ (1)

Keterangan :

$\mathrm{TK}_{\mathrm{it}} \quad$ : Jumlah tenaga kerja setiap Kabupaten/kota provinsi Jawa
Tengah pada tahun $\mathrm{t}$ (dalam jiwa)

\begin{tabular}{|c|c|c|}
\hline $\mathrm{LPE}_{\mathrm{it}}$ & : & $\begin{array}{l}\text { Pertumbuhan ekonomi setiap } \\
\text { Kabupaten/kota Provinsi } \\
\text { Jateng pada tahun t (dalam } \\
\text { persen). }\end{array}$ \\
\hline $\mathrm{UMK}_{\mathrm{it}}$ & : & $\begin{array}{l}\text { Nilai Upah Minimum di setiap } \\
\text { Kabupaten/kota di Provinsi } \\
\text { Jawa Tengah pada tahun } \mathrm{t} \\
\text { (dalam rupiah) }\end{array}$ \\
\hline $\mathrm{UUI}_{\mathrm{it}}$ & : & $\begin{array}{l}\text { Jumlah Unit Usaha Industri } \\
\text { setiap Kabupaten/kota di } \\
\text { provinsi Jawa Tengah pada } \\
\text { tahun t (dalam unit) }\end{array}$ \\
\hline$\varepsilon_{\text {it }}$ & : & Komponen error \\
\hline I & $:$ & Kabupaten/Kota \\
\hline $\mathrm{T}$ & : & Tahun \\
\hline
\end{tabular}

\section{ANALISIS DATA DAN PEM- BAHASAN}

\section{Gambaran Data Penelitian}

PDRB Atas Dasar Harga Konstan Provinsi Jawa Tengah menunjukkan peningkatan dari tahun 2010 (sebesar Rp 186.992.985,50 juta) sampai dengan 2014 (sebesar Rp 235.298.299,13 juta). Dilihat dari laju pertumbuhannya setiap tahun meningkat dengan rata-rata 5,9\%. Secara rinci data PDRB Atas Dasar Harga Konstan daan laju pertumbuhannya dari tahun 2010-2014 dapat dilihat pada tabel 1 .

Tabel 1

PDRB Atas Dasar Harga Konstan dan Laju Pertumbuhannya

Provisni Jawa Tengah Tahun 2010-2014

\begin{tabular}{|c|c|c|}
\hline Tahun & $\begin{array}{c}\text { PDRB Atas Dasar } \\
\text { Harga Konstan } \\
\text { (juta Rp) }\end{array}$ & $\begin{array}{c}\text { Laju } \\
\text { Pertumb } \\
\text { uhan } \\
(\%)\end{array}$ \\
\hline 2010 & $186.992 .985,50$ & 5,84 \\
\hline 2011 & $198.270 .117,94$ & 6,03 \\
\hline 2012 & $210.848 .424,04$ & 6,34 \\
\hline 2013 & $223.099 .740,34$ & 5,81 \\
\hline 2014 & $235.298 .299,13$ & 5,47 \\
\hline
\end{tabular}

Sumber : BPS Provinsi Jawa Tengah, 2015 
Distribusi persentase PDRB menurut lapangan usaha atas dasar harga konstan di Provinsi Jawa Tengah 2008-2014 memperlihatkan bahwa sektor ekonomi yang memberikan kontribusi terbesar dalam perekonomian Jawa Tengah adalah sektor industri pengolahan (tabel 2).

Tabel 2

Distribusi Persentase PDRB Menurut Lapangan Usaha Atas Dasar Harga Konstan di Provinsi Jawa Tengah 2008 - 2014

\begin{tabular}{|c|c|c|c|c|c|c|c|}
\hline $\begin{array}{c}\text { Lapan } \\
\text { gan } \\
\text { Usaha }\end{array}$ & 2008 & 2009 & 2010 & 2011 & 2012 & 2013 & 2014 \\
\hline $\begin{array}{l}\text { 1.Pert } \\
\text { anian }\end{array}$ & $\begin{array}{r}19,8 \\
5\end{array}$ & $\begin{array}{r}19,9 \\
4\end{array}$ & $\begin{array}{r}19,4 \\
9\end{array}$ & $\begin{array}{r}19,0 \\
6\end{array}$ & 18,74 & 18,30 & 15,77 \\
\hline $\begin{array}{l}\text { 2.Pert } \\
\text { amba } \\
\text { ngan } \\
\& \\
\text { Pengg } \\
\text { alian }\end{array}$ & 0,96 & 0,97 & 0,97 & 0,95 & 0,94 & 0,96 & 1,13 \\
\hline $\begin{array}{l}\text { 3.Ind } \\
\text { ustri } \\
\text { Pengo } \\
\text { lahan }\end{array}$ & $\begin{array}{r}34,0 \\
5\end{array}$ & $\begin{array}{r}32,7 \\
6\end{array}$ & $\begin{array}{r}32,8 \\
6\end{array}$ & $\begin{array}{r}33,2 \\
5\end{array}$ & 32,83 & 32,56 & 33,05 \\
\hline $\begin{array}{l}\text { 4.List } \\
\text { rik, } \\
\text { Gas \& } \\
\text { Air } \\
\text { Bersih }\end{array}$ & 1,02 & 1,03 & 1,04 & 1,02 & 1,02 & 1,06 & 0,89 \\
\hline $\begin{array}{l}\text { 5.Ban } \\
\text { gunan }\end{array}$ & 5,77 & 6,14 & 6,10 & 5,99 & 5,99 & 5,96 & 6,03 \\
\hline $\begin{array}{l}\text { 6.Perda } \\
\text { Hotel \& } \\
\text { Restora }\end{array}$ & $\begin{array}{r}19,5 \\
1\end{array}$ & $\begin{array}{r}19,6 \\
7\end{array}$ & $\begin{array}{r}19,5 \\
6\end{array}$ & $\begin{array}{r}19,7 \\
4\end{array}$ & 20,29 & 20,73 & 22,92 \\
\hline $\begin{array}{l}\text { 7.Pen } \\
\text { gangk } \\
\text { utan } \\
\& \& \\
\text { Komu } \\
\text { nikasi }\end{array}$ & 5,74 & 5,99 & 5,91 & 5,85 & 5,92 & 6,03 & 5,60 \\
\hline $\begin{array}{l}\text { 8.Keu } \\
\text { angan } \\
\text {, sewa, } \\
\& \\
\text { Jasa } \\
\text { Perus } \\
\text { ahaan }\end{array}$ & 3,44 & 3,63 & 3,58 & 3,55 & 3,59 & 3,73 & 4,19 \\
\hline $\begin{array}{l}\text { 9.Jasa } \\
\text {-Jasa }\end{array}$ & 9,66 & 9,86 & $\begin{array}{r}10,4 \\
8\end{array}$ & $\begin{array}{r}10,5 \\
9\end{array}$ & 10,67 & 10,67 & 10,42 \\
\hline PDRB & $\begin{array}{r}100, \\
00\end{array}$ & $\begin{array}{r}100, \\
00\end{array}$ & $\begin{array}{r}100, \\
00\end{array}$ & $\begin{array}{r}100, \\
00\end{array}$ & $\begin{array}{r}100,0 \\
0\end{array}$ & $\begin{array}{r}100,0 \\
0\end{array}$ & $\begin{array}{r}100,0 \\
0\end{array}$ \\
\hline
\end{tabular}

Sumber : BPS Provinsi Jawa Tengah, 2015.

Selanjutnya data mengenai jumlah tenaga kerja yang bekerja me- nurut lapangan usaha di Provinsi Jawa Tengah menunjukkan sektor industri merupakan sektor ketiga penyerap tenaga kerja terbanyak selama periode 2010-2014, setelah sektor pertanian dan sektor perdagangan (Badan Pusat Statistik Provinsi Jawa Tengah, 2015). Selengkapnya dapat dilihat pada tabel 3 .

Tabel 3

Penduduk Berumur 15 Tahun ke Atas yang Bekerja Menurut

Lapangan Pekerjaan Utama di Jawa Tengah Tahun 2010 - 2014

\begin{tabular}{|c|c|c|c|c|c|}
\hline \multirow{2}{*}{$\begin{array}{l}\text { Lapangan } \\
\text { Pekerjaan }\end{array}$} & \multicolumn{5}{|c|}{ Tahun } \\
\hline & 2010 & 2011 & 2012 & 2013 & 2014 \\
\hline 1. Pertanian & $\begin{array}{r}5.616 . \\
529\end{array}$ & $\begin{array}{r}5.37 \\
6.45 \\
2\end{array}$ & $\begin{array}{r}5.06 \\
4.37 \\
7\end{array}$ & $\begin{array}{r}4.92 \\
6.62 \\
9\end{array}$ & $\begin{array}{r}5.173 . \\
986\end{array}$ \\
\hline $\begin{array}{l}\text { 2. Pertamba } \\
\text { ngan, } \\
\text { Galian,L } \\
\text { istrik, } \\
\text { Gas dan } \\
\text { Air } \\
\end{array}$ & $\begin{array}{r}13 \\
6.62 \\
5\end{array}$ & $\begin{array}{l}108 \\
.592\end{array}$ & $\begin{array}{r}1 \\
17.7 \\
72\end{array}$ & $\begin{array}{r}8 \\
7.14 \\
3\end{array}$ & $\begin{array}{l}115 \\
.201\end{array}$ \\
\hline 3. Industri & $\begin{array}{r}2.81 \\
5.29 \\
2\end{array}$ & $\begin{array}{r}3.04 \\
6.72 \\
4\end{array}$ & $\begin{array}{r}3.29 \\
7.70 \\
7\end{array}$ & $\begin{array}{r}3.04 \\
4.42 \\
8\end{array}$ & $\begin{array}{r}3.17 \\
3.21 \\
7\end{array}$ \\
\hline $\begin{array}{l}\text { 4. Konstruks } \\
\mathrm{i}\end{array}$ & $\begin{array}{r}1.04 \\
6.74 \\
1\end{array}$ & $\begin{array}{r}1.09 \\
7.38 \\
0\end{array}$ & $\begin{array}{r}1.20 \\
7.06 \\
7\end{array}$ & $\begin{array}{r}95 \\
0.57 \\
8\end{array}$ & $\begin{array}{r}1.26 \\
9.11 \\
3\end{array}$ \\
\hline $\begin{array}{l}\text { 5. Perdagan } \\
\text { gan }\end{array}$ & $\begin{array}{r}3.38 \\
8.45 \\
0\end{array}$ & $\begin{array}{r}3.40 \\
2.09 \\
1\end{array}$ & $\begin{array}{r}3.44 \\
7.14 \\
7\end{array}$ & $\begin{array}{r}3.58 \\
5.59 \\
6\end{array}$ & $\begin{array}{r}3.71 \\
5.48 \\
8\end{array}$ \\
\hline $\begin{array}{l}\text { 6. Transport } \\
\text { asi }\end{array}$ & $\begin{array}{l}664 \\
.080\end{array}$ & $\begin{array}{r}563 \\
.44\end{array}$ & $\begin{array}{r}54 \\
7.94 \\
4\end{array}$ & $\begin{array}{r}60 \\
3.86 \\
2\end{array}$ & $\begin{array}{r}58 \\
7.39 \\
1\end{array}$ \\
\hline 7. Keuangan & $\begin{array}{l}179 \\
.804\end{array}$ & $\begin{array}{r}26 \\
4.68 \\
1\end{array}$ & $\begin{array}{r}28 \\
2.81 \\
0\end{array}$ & $\begin{array}{r}31 \\
4.24 \\
6\end{array}$ & $\begin{array}{r}32 \\
2.40 \\
2\end{array}$ \\
\hline 8. Jasa & $\begin{array}{r}1.96 \\
1.92 \\
6\end{array}$ & $\begin{array}{r}2.05 \\
7.07 \\
1\end{array}$ & $\begin{array}{r}2.16 \\
8.06 \\
6\end{array}$ & $\begin{array}{r}2.45 \\
1.56 \\
6\end{array}$ & $\begin{array}{r}2.93 . \\
884\end{array}$ \\
\hline Jumlah & $\begin{array}{r}15.8 \\
09.4 \\
47\end{array}$ & $\begin{array}{r}15.916 . \\
135\end{array}$ & $\begin{array}{r}16.1 \\
32.8 \\
90\end{array}$ & $\begin{array}{r}15.9 \\
64.0 \\
48\end{array}$ & $\begin{array}{r}16.550 \\
.682\end{array}$ \\
\hline
\end{tabular}

Sumber : BPS Provinsi Jawa Tengah, 2015. 
Badan Penanaman Modal Daerah Jawa Tengah melihat bahwa para investor asing tertarik untuk berinvestasi di Jawa Tengah dengan konsep usaha yang bersifat padat karya. Sumber daya manusia yang tersedia di Jawa tengah sangat kompetitif dibandingkan daerah yang lain, di antaranya dari segi upah dan kemampuan. Separuh populasi masyarakat Jawa Tengah merupakan usia produktif untuk angkatan kerja. Sementara itu, melihat kondisi geografis Jawa Tengah, masih banyak daerah yang bisa dijadikan sebagai kawasan industri. Hal ini yang menjadi daya tarik investor asing untuk membangun perusahaan yang bersifat padat karya. Keberadaan Sektor industri pengolahan mampu menyerap angkatan kerja baru. Industri manufaktur merupakan salah satu penopang perekonomian yang dianggap tangguh di Provinsi Jawa Tengah. Perkembangan jumlah perusahaan/unit usaha menurut jenis industri di Jawa Tengah Tahun 2009 - 2013 disajikan pada tabel 4.

Tabel 4

Jumlah Perusahaan/Unit Usaha Menurut Jenis Industri

di Jawa Tengah Tahun 2009 - 2013

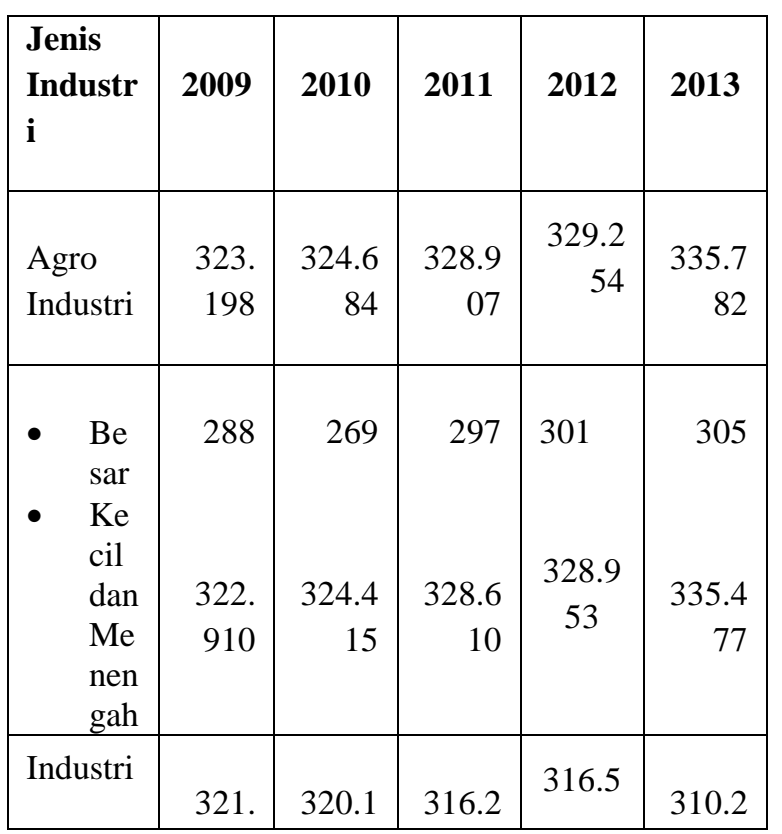

\begin{tabular}{|c|c|c|c|c|c|}
\hline & 271 & 81 & 52 & 86 & 13 \\
\hline \multirow{3}{*}{$\begin{array}{ll}-\quad \mathrm{Be} \\
\text { - } & \mathrm{Sar} \\
\mathrm{Ke} \\
\text { cil } \\
\text { dan } \\
\mathrm{Me} \\
\text { nen } \\
\text { gah }\end{array}$} & 501 & 495 & 528 & 534 & 542 \\
\hline & 320. & 319.6 & 315.7 & \multirow{2}{*}{$\begin{array}{r}316.0 \\
52\end{array}$} & 309.6 \\
\hline & 770 & 86 & 24 & & 71 \\
\hline \multirow[b]{2}{*}{ Jumlah } & 644 & 6448 & 6451 & 6458 & 6459 \\
\hline & 469 & 64 & 59 & 40 & 95 \\
\hline \multirow{4}{*}{$\begin{array}{ll}\text { - } & \text { Be } \\
\text { sar } \\
\text { - } & \text { Ke } \\
\text { cil } \\
\text { dan } \\
\text { me } \\
\text { nen } \\
\text { gah }\end{array}$} & 789 & 764 & 825 & 835 & 847 \\
\hline & 643. & 644.1 & 644.3 & 645.0 & 645.1 \\
\hline & 680 & 01 & 34 & 05 & 48 \\
\hline & & & & & \\
\hline
\end{tabular}

Sumber: Dinas Perindustrian Provinsi Jawa Tengah, 2014.

Seiring dengan meningkatnya jumlah unit usaha industri di Jawa Tengah, jumlah tenaga kerja yang bekerja di sektor industri, juga meningkat dari tahun ke tahun. Pada tahun 2004 sebesar 14,9 juta jiwa, bertambah menjadi 16,2 juta jiwa di tahun 2013, atau meningkat sekitar $8,7 \%$. Data jumlah tenaga kerja di sektor industri dihubungkan dengan besaran upah minimum, maka besaran upah minimum provinsi juga menunjukkan peningkatan dari tahun ke tahun, dari sebesar Rp 359.210 per bulan pada tahun 2004 menjadi sebesar Rp 643.960 per bulan pada tahun 2013, atau meningkat sekitar 179,3 $\%$. Dapat dinyatakan bahwa meskipun upah meningkat, jumlah tenaga kerja yang terserap pun juga meningkat. Selengkapnya data mengenai besaran upah minimum provinsi dan jumlah tenaga kerja yang bekerja di sektor industri dapat dilihat pada tabel 5. 
Tabel 5

Besaran Upah Minimum Propinsi dan Jumlah Tenaga Kerja Sektor Industri Di Provisni Jawa Tengah Tahun $2004-2013$

\begin{tabular}{|c|c|c|}
\hline Tahun & $\begin{array}{l}\text { Upah Minimum } \\
\text { Provinsi } \\
\text { (Rp/bln) }\end{array}$ & $\begin{array}{l}\text { Jumlah Tenaga } \\
\text { Kerja Sektor } \\
\text { Industri } \\
\text { (orang) }\end{array}$ \\
\hline 2004 & 359.210 & 14.930 .097 \\
2005 & 356.394 & 15.655 .303 \\
2006 & 371.376 & 15.210 .931 \\
2007 & 397.948 & 16.304 .058 \\
2008 & 455.457 & 15.463 .658 \\
2009 & 522.585 & 15.835 .382 \\
2010 & 556.070 & 15.809 .447 \\
2011 & 557.943 & 15.916 .135 \\
2012 & 614.705 & 16.132 .890 \\
2013 & 643.960 & 16.232 .000 \\
\hline
\end{tabular}

Sumber : Badan Pusat Statistik, 2014.

\section{Hasil Analisis Regresi}

Model estimasi regresi data panel terhadap faktor yang mempengaruhi penyerapan tenaga kerja sektor industri di Jawa Tengah meliputi Common Effect, Fixed Effect dan Random Effect. Faktor yang mempengaruhi penyerapan tenaga kerja sektor industri di Jawa Tengah meliputi pertumbuhan ekonomi, upah minimum Kabupaten/Kota dan jumlah unit usaha industri. Hasil analisis regresi tersebut disajikan dalam tabel 6.
Tabel 6

Hasil Regresi Penyerapan Tenaga Kerja di Provinsi Jawa Tengah

Tahun 2010 - 2014

\begin{tabular}{|c|c|c|c|c|c|}
\hline $\mathrm{N}$ & $\begin{array}{c}\text { Varia } \\
\text { bel }\end{array}$ & $\begin{array}{c}\text { Not } \\
\text { asi }\end{array}$ & $\begin{array}{c}\text { Common } \\
\text { Effect }\end{array}$ & $\begin{array}{l}\text { Fixed } \\
\text { Effect }\end{array}$ & $\begin{array}{c}\text { Random } \\
\text { Effect }\end{array}$ \\
\hline 1 & $\begin{array}{l}\text { Konst } \\
\text { anta }\end{array}$ & $\beta_{0}$ & $\begin{array}{c}58.799,1 \\
400 \\
(1,8896) \\
0,0605\end{array}$ & $\begin{array}{c}40.56 \\
7, \\
2900 \\
(2,80 \\
89) \\
\\
0,005 \\
7\end{array}$ & $\begin{array}{c}20.192,6 \\
400 \\
(1,3914) \\
0,1659\end{array}$ \\
\hline 2 & $\begin{array}{l}\text { Laju } \\
\text { Pertu } \\
\text { mbuh } \\
\text { an } \\
\text { Ekon } \\
\text { omi }\end{array}$ & $\begin{array}{c}\text { LP } \\
\text { E }\end{array}$ & $\begin{array}{c}- \\
3.381,83 \\
10 \\
(-0,8338) \\
0,4056\end{array}$ & $\begin{array}{c}3.809 \\
, 1490 \\
\\
(2,69 \\
32) \\
0,008 \\
0\end{array}$ & $\begin{array}{c}3.891,67 \\
60 \\
(2,7671) \\
0,0063\end{array}$ \\
\hline 3 & $\begin{array}{l}\text { Upah } \\
\text { Mini } \\
\text { mum } \\
\text { Kabu } \\
\text { paten/ } \\
\text { Kota }\end{array}$ & $\begin{array}{c}\mathrm{UM} \\
\mathrm{K}\end{array}$ & $\begin{array}{c}0,0020 \\
(0,0849) \\
0,9325\end{array}$ & $\begin{array}{c}0,023 \\
9 \\
(2,96 \\
19) \\
\\
0,003 \\
6\end{array}$ & $\begin{array}{c}0,0270 \\
(3,3941) \\
0,0009\end{array}$ \\
\hline 4 & $\begin{array}{l}\text { Unit } \\
\text { usaha } \\
\text { indust } \\
\text { ri }\end{array}$ & $\begin{array}{l}\text { (U } \\
\mathrm{UI})\end{array}$ & $\begin{array}{c}417,7122 \\
(11,2360 \\
) \\
0,0000\end{array}$ & $\begin{array}{c}62,89 \\
75 \\
\\
(0,86 \\
87) \\
\\
0,386 \\
5\end{array}$ & $\begin{array}{c}223,1974 \\
(4,1610) \\
0,0001\end{array}$ \\
\hline & \multicolumn{2}{|c|}{ R-squared } & 0,4331 & $\begin{array}{c}0,961 \\
2\end{array}$ & 0,1432 \\
\hline & $\begin{array}{l}\text { Adjusted } \\
\text { square }\end{array}$ & & 0,4231 & $\begin{array}{c}0,950 \\
8\end{array}$ & 0,1282 \\
\hline & F-statis & & $\begin{array}{r}43,5420 \\
0,0000\end{array}$ & $\begin{array}{c}91,87 \\
27 \\
0,000\end{array}$ & $\begin{array}{l}9,5270 \\
0,0000\end{array}$ \\
\hline
\end{tabular}




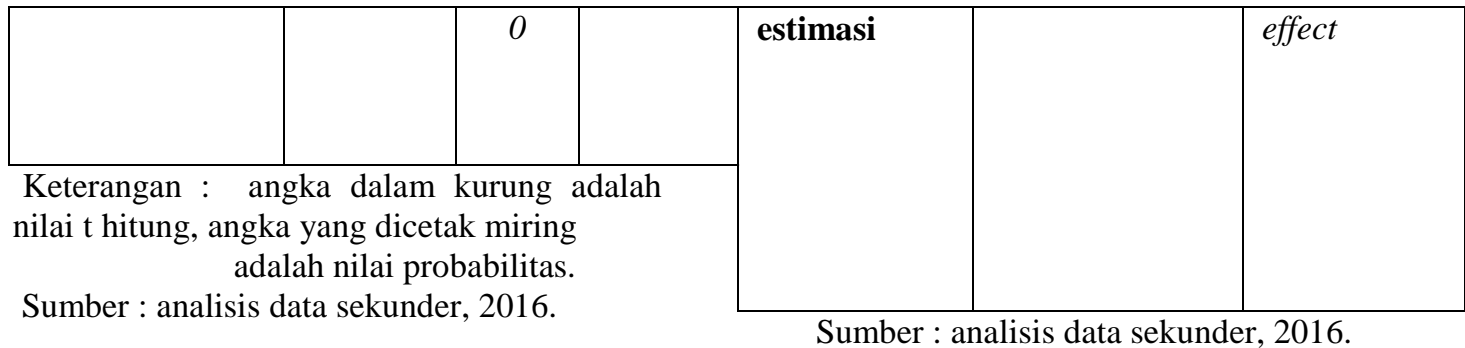

Hasil pengujian model dapat dilihat pada tabel 7, meliputi uji statistik F, Uji Lagrange Multiplier (LM) dan uji Hausman. Berdasarkan pengujian tersebut, disimpulkan bahwa model estimasi terhadap faktor yang mempengaruhi penyerapan tenaga kerja sektor industri di Jawa Tengah adalah model fixed effect.

Tabel 7.

Hasil Uji Signifikansi Model

\begin{tabular}{|c|c|c|}
\hline $\begin{array}{l}\text { Uji Fixed } \\
\text { Effect : } \\
\text { Uji F } \\
\text { Statistik }\end{array}$ & $\begin{array}{l}\text { Uji Random } \\
\text { Effect : } \\
\text { Uji } \\
\text { LM/Breusch- } \\
\text { Pagan }\end{array}$ & $\begin{array}{l}\text { Uji Fixed } \\
\text { atau } \\
\text { Random } \\
\text { Effect : } \\
\text { Hausman } \\
\text { Test }\end{array}$ \\
\hline $\begin{array}{l}\text { F hitung : } \\
54,9358\end{array}$ & $\begin{array}{l}\text { LM }\left(X^{2}\right) \text { hitung } \\
267,7629\end{array}$ & $\begin{array}{l}X^{2} \text { hitung : } \\
14,6019\end{array}$ \\
\hline $\begin{array}{l}\text { F tabel }(= \\
0,05, \quad \text { df } \\
(34,137)): \\
1,5152\end{array}$ & $\begin{array}{l}\mathrm{X}^{2} \text { tabel }(=0,05 \\
\mathrm{df}(3)): 7.8147\end{array}$ & $\begin{array}{l}\mathrm{X}^{2} \text { tabel }(= \\
0,05 \\
\operatorname{df}(3)): \\
7.8147\end{array}$ \\
\hline $\begin{array}{l}\text { F tabel }(= \\
0,01, \\
\operatorname{df}(34,137)): \\
1,7945\end{array}$ & $\begin{array}{l}X^{2} \text { tabel }(=0,01, \\
\operatorname{df}(3)): 11,3449\end{array}$ & $\begin{array}{l}X^{2} \text { tabel }(= \\
0,01, \operatorname{df}(3)): \\
11,3449\end{array}$ \\
\hline $\begin{array}{l}\text { Kesimpulan } \\
\text { : } \\
\text { F hitung > F } \\
\text { tabel, maka } \\
\text { signifikan, } \\
\text { sehingga } \\
\text { fixed effect } \\
\text { adalah } \\
\text { model yang } \\
\text { tepat untuk }\end{array}$ & $\begin{array}{l}\text { Kesimpulan: } \\
\mathrm{X}^{2} \text { hitung > } \mathrm{X}^{2} \\
\text { tabel, maka } \\
\text { random effect } \\
\text { Adalah model } \\
\text { estimasi yang } \\
\text { tepat }\end{array}$ & $\begin{array}{l}\text { Kesimpulan } \\
: \\
\mathrm{X}^{2} \text { hitung > } \\
\mathrm{X}^{2} \text { tabel, } \\
\text { maka fixed } \\
\text { effect adalah } \\
\text { model yang } \\
\text { tepat } \\
\text { dibanding } \\
\text { random }\end{array}$ \\
\hline
\end{tabular}

Berdasar hasil yang sudah disajikan dalam tabel 6 untuk model fixed effect dapat ditulis persamaan regresinya sebagai berikut :

\begin{tabular}{|c|c|c|c|c|}
\hline I hix - & 40.567240 & $3.809,1 \pm 1]$ & $+0,023 \mathrm{yU}:$ & +628 S $75 U L$ L \\
\hline thinulg, & $(2,8080)$ & $(2.6032)$ & $(2,619)$ & $(0,8687)$ \\
\hline Trubuixdilns. & 6,0657 & 50250 & 60030 & 6,2353 \\
\hline F hiturg & $91,8: 27$ & perabslit & a,o(ii) & \\
\hline
\end{tabular}

Hasil analisis regresi tersebut menunjukkan bahwa secara bersama-sama variabel laju pertumbuhan ekonomi, upah minimum dan jumlah unit usaha industri berpengaruh terhadap penyerapan tenaga kerja di Provinsi Jawa Tengah. Secara parsial, variabel laju pertumbuhan ekonomi dan upah minimum berpengaruh positif terhadap penyerapan tenaga kerja, sedangkan jumlah unit usaha industri tidak berpengaruh terhadap penyerapan tenaga kerja di Provinsi Jawa Tengah.

Pengaruh positif laju pertumbuhan ekonomi terhadap penyerapan tenaga kerja mempunyai arti bahwa semakin tinggi pertumbuhan ekonomi di Jawa Tengah, maka akan semakin banyak penyerapan tenaga kerja. Besarnya koefisien regresi sebesar 3.809,1490 menunjukkan bahwa kenaikan laju pertumbuhan ekonomi sebesar $1 \%$ akan meningkatkan penyerapan tenaga kerja sebesar 3.809 jiwa dengan asumsi variabel lain tetap. Hasil ini sesuai dengan penelitian yang dilakukan oleh Miar (2014) dan Tambunsaribu (2013), bahwa pertumbuhan ekonomi berpengaruh positif terhadap penyerapan tenaga kerja. 
Pengaruh positif laju pertumbuhan ekonomi terhadap penyerapan enaga kerja sektor industri ditunjukkan oleh tingkat aktivitas ekonomi yang selalu mengalami trend positif sebagaimana grafik 2. Terjadinya pertumbuhan ekonomi akan menggerakan sektorsektor lainnya, sehingga dari sisi produksi akan memerlukan tenaga kerja. Kemampuan dalam menghasilkan output oleh sektor industri tersebut tentunya tidak terlepas dari peran tenaga kerja dalam proses produksinya, sehingga semakin besar output yang dihasilkan maka menggambarkan semakin besar jumlah tenaga kerja yang dibutuhkan untuk menghasilkan output tersebut. Perkembangan ekonomi selanjutnya di Provinsi Jawa Tengah juga nampak pada Pendapatan Regional perkapita atas dasar harga berlaku dari Tahun 2010-2013 meningkat setiap tahunnya sebagaimana grafik 3 .

Grafik 2.

Pertumbuhan Ekonomi Jawa Tengah 20102014

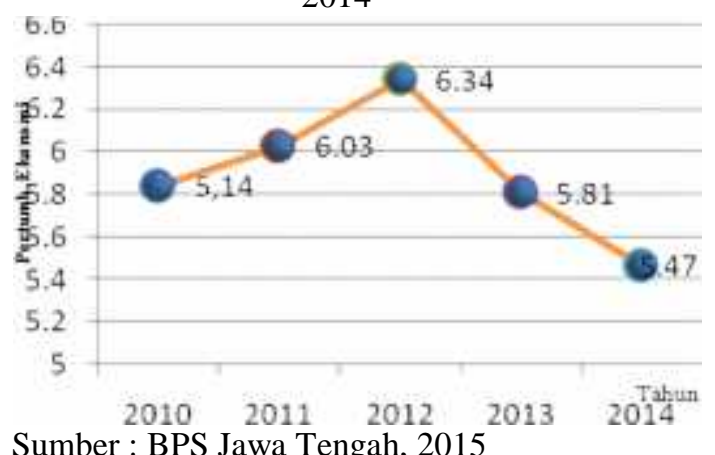

Grafik 3

Pendapatan Regional perkapita Atas Dasar Harga Berlaku

Provinsi Jawa Tengah, Tahun 2008-2013

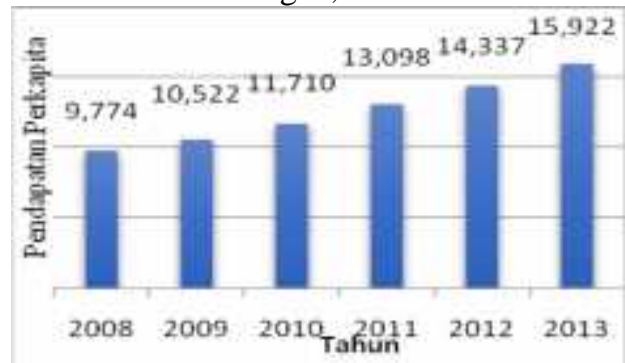

Sumber : BPS Jawa Tengah, 2015
Pengaruh upah minimum kabupaten/kota terhadap penyerapan tenaga kerja adalah positif. Ini artinya, naiknya upah minimum akan meningkatkan penyerapan tenaga kerja dan begitu juga sebaliknya, turunnya upah minimum akan menurunkan jumlah penyerapan tenaga kerja di sektor industri. Besarnya nilai koefisien regresi adalah 0,0239 menunjukkan bahwa apabila upah minimum naik satu rupiah maka nilai penyerapan tenaga kerja juga akan meningkat sebesar 0,0239 jiwa, atau jika upah minimum naik 10.000 rupiah maka nilai penyerapan tenaga kerja juga akan meningkat sebesar 239 jiwa dengan asumsi variabel lain konstan. Temuan ini bertolak belakang dengan teori dan beberapa hasil penelitian teradahulu. Teori hubungan upah minimum dan penyerapan tenaga kerja menjelaskan bahwa pemberlakuan upah minimum dapat menyebabkan pengangguran, namun dalam beberapa kasus pergeseran ini pada kenyataannya dapat menyebabkan perusahaan yang bersangkutan meningkatkan masukan tenaga kerja yang memaksimumkan laba. Artinya untuk memaksimalkan laba, perusahaan terus menarik tenaga kerja sampai pada titik dimana produk marjinal tenaga kerja sama dengan upah riil (Mankiw, 2003:51). Sementara itu Sumarsono (2003) menyatakan upah akan mempengaruhi tinggi rendahnya biaya produksi yang dapat mengakibatkan pengurangan ataupun penambahan jumlah penyerapan tenaga kerja.

Beberapa hasil penelitian terdahulu yang bertolak belakang dengan temuan penelitian ini adalah hasil penelitian Greer, Castrejon \& Lee (2014) dan penelitian Sobita \& Saputra (2014). Hasil penelitian Greer, Castrejon \& Lee (2014) menyimpulkan bahwa upah minimum memiliki dampak yang signifikan terhadap pengang- 
guran ketika ekonomi tidak stabil, selama resesi dan pasca-resesi, yaitu bahwa peningkatan upah minimum meningkatkan pengangguran, atau upah minimum mempunyai pengaruh negatif terhadap penyerapan tenaga kerja. Selanjutnya hasil penelitian Sobita \& Saputra (2014) menyatakan bahwa upah riil secara signifikan berpengaruh negatif terhadap penyerapan tenaga kerja.

Beberapa penelitian yang mendukung upah berpengaruh positif terhadap penyerapan tenaga kerja adalah penelitian yang dilakukan oleh Saputri \& Rejekiningsih (2008), variabel upah berpengaruh positif terhadap penyerapan tenaga. Hal ini dikarenakan upah yang digunakan dalam penelitian adalah upah minimum kota (UMK), dimana UMK memiliki pergerakan yang relatif stabil dan ditentukan oleh Tripartit (Pengusaha, Serikat Pekerja dan Pemerintah). Selain itu, dimungkinkan adanya kinerja yang aktif dari serikat pekerja, yang tidak hanya melindungi pekerja tetapi juga memperhatikan hidup pengusaha, sehingga ada hubungan yang baik antara serikat kerja dan pengusaha. Pengaruh positif UMK teradap penyerapan tenaga kerja di Provinsi Jawa Tengah didukung fakta bahwa Jawa Tengah memiliki faktor produksi tenaga kerja relatif banyak, sehingga memproduksi barang yang padat karya. Sumber daya manusia yang tersedia di Jawa tengah sangat kompetitif dibandingkan daerah yang lain di antaranya dari segi upah dan kemampuan. Separuh populasi masyarakat Jawa Tengah merupakan usia produktif untuk angkatan kerja. Sementara itu, melihat kondisi geografis Jawa Tengah, masih banyak daerah yang bisa dijadikan sebagai kawasan industri padat karya. Industri yang bersifat padat karya dan berorientasi ekspor inilah yang diduga menjadi penyebab kenaikan upah minimum berpengaruh positif terhadap penyerapan tenaga kerja.

Jumlah unit usaha industri tidak berpengaruh terhadap penyerapan tenaga kerja. Hal ini terkait dengan kondisi industri di Provinsi Jawa Tengah yang bersifat padat karya sehingga penyerapan tenaga kerja tidak terpengaruh dengan banyak atau sedikitnya keberadaan unit usaha. Pada kenyataannya dengan jumlah unit usaha yang terbatas telah mampu menyerap tenaga kerja dalam jumlah yang relatif banyak.

\section{KESIMPULAN, IMPLIKASI, SARAN, DAN BATASAN}

Berdasarkan hasil penelitian dapat ditarik kesimpulan bahwa secara bersama-sama variabel laju pertumbuhan ekonomi, upah minimum Kabupaten/kota dan jumlah unit usaha ndustri berpengaruh terhadap penyerapan tenaga kerja di Provinsi Jawa Tengah. Secara parsial laju pertumbuhan ekonomi dan upah minimum kabupaten/kota berpengaruh positif terhadap penyerapan tenaga kerja sektor industri, sedangkan jumlah unit usaha industri tidak berpengaruh terhadap penyerapan tenaga kerja.

Berdasarkan hasil penelitian, beberapa saran yang direkomendasikan dalam rangka memberikan masukan terhadap kebijakan ketenegakerjaan di Provinsi Jawa Tengah adalah perlunya upaya pemerintah untuk mendorong laju pertumbuhan ekonomi. Pemerintah dan para pelaku usaha perlu lebih memperhatikan dan menggalakkan dukungan ekonominya terhadap sektor industri pengolahan, perdagangan hotel dan restoran, serta pertanian dibanding dengan sektor lain. Hal ini mengingat ketiga sektor ini menempati urutan tiga besar dalam kontribusinya terhadap laju pertum- 
buhan ekonomi. Ketiga sektor ini juga memberikan andil terbesar dalam penyerapan tenaga kerja. Pemerintah perlu melakukan pendataan dan memetakan daerah mana yang cocok untuk pengembangan kawasan industri, untuk itu pemerintah perlu bersinergi dengan pengusaha khususnya dalam hal meningkatkan industri yang banyak menyerap tenaga kerja. Pemerintah hendaknya memberi dukungan strategis berupa penataan dan penyelesaian masalah pembebasan lahan, perizinan, dan mempercepat pelaksanaan proyek investasi sebagai dukungan terhadap perkembangan industri padat karya di Provinsi Jawa Tengah.

\section{DAFTAR PUSTAKA}

Arsyad, Lincolin. (2010). Ekonomi Pembangunan. Yogyakarta: STIE YKPN

Badan Pusat Statistik Provinsi Jawa Tengah. Jawa Tengah Dalam Angka 2009-2016. (2012). Hasil Re-

konsiliasi PDRB se Jawa Tengah. (2015). Profil

Ketenagakerjaan Jawa Tengah Hasil Sakernas Agustus 2014. Mei Tahun 2015.

Bappenas. (2014). Perkembangan Pembangunan Provinsi Jawa Tengah 2014.

Dumairy. (1996). Perekonomian Indonesia. Jakarta: Erlangga

Greer, Scott \& Castrejon, Isai \& Lee Sarah. (2014). "The Effect of Minimum Wage and Unemployment Across Varying Economic Climates". Georgia Institute of Technology.
Diakses 28 Desember 2015 pukul 09.17 WIB.

Indradewa, I Gusti Agung. (2015). "Pengaruh Inflasi, Produk Domestik Regional Bruto (PDRB), dan Upah Minimum Terhadap Penyerapan Tenaga Kerja di Provinsi Bali Periode Tahun 1994-2013”. Skripsi. Universitas Udayana. Denpasar.

Mankiw, N. Gregory. (2003). Teori Makro Ekonomi. Terjemahan. Jakarta: PT. Gramedia Pustaka Utama

Miar Piter. (2014). "Influence of Economic Growth to Manpower Absorption and People elfare in Regencies/Cities in Central Kalimantan Province". Journal of Economics and Sustainable Development Vol.5, No.21, www.iiste.orgISSN2222-1700 (Paper) ISSN 2222-2855 (Online), Diakses Tanggal 6 Nopember 2015 pukul 16.48 WIB.

Muana, Nanga. (2001). Makro Ekonomi, Masalah dan Kebijakan. Jakarta: PT. Raja Grafindo Persada

Munasriah. (2015). "Pengaruh Jumlah Unit Usaha dan Investasi Terhadap Penyerapan Tenaga Kerja Pada Industri Kecil Di Kabupaten Wajo." Tesis. Program Pasca Sarjana, Universitas Hasanudin.Makasar.http://repository. unhas.ac.id:4001/digilib/files/disk1/4 00. Diakses Tanggal 27 April 2016 pukul 22.12 WIB.

Karib, Abdul MS. (2012). "Analisis Pengaruh Produksi, Investasi Dan Unit Usaha Terhadap Penyerapan Tenaga Kerja Pada Sektor Industri Sumatera Barat". Jurnal Manajemen dan Kewirausahaan, Volume 3, Nomor 3, September 2012 ISSN : 2086 -5031. Universitas Andalas. Padang, Diakses 
Tanggal 6 Maret 2016 pukul 21.20 WIB.

Saputri, Oktaviana Dwi \& Rejekiningsih, Tri Wahyu. (2008).

"Analisis Penyerapan Tenaga Kerja di Kota Salatiga "Jurnal Analisis. http://eprints.undip.ac.id/29404/1/. Diakses tanggal 27 April 2016 pukul 23.43 WIB.

Sobita, Nindya Eka \& Suparta, I Wayan. (2014). "Pertumbuhan Ekonomi dan Penyerapan Tenaga Kerja di Provinsi Lampung" JEP. Vol. 3, No. 2, Juli 2014,Diakses 19 Maret 2016 pukul 21.54 WIB.

Simanjuntak, Payaman J. (2001). Ekonomi Sumber Daya Manusia. Lembaga Penerbit Fakultas Ekonomi Universitas Indonesia : Jakarta.

Tambunsaribu, Romas Yossia. (2013). "Analisis Pengaruh Produktivitas Tenaga Kerja, Upah Riil dan Pertumbuhan Ekonomi terhadap Penyerapan Tenaga Kerja di 35 Kabupaten/Kota Jawa Tengah." Diponegoro Journal of Economics, http://ejournals1.undip.ac.id/index.php/jme. Diakses 7 Maret 2016 pukul 23.21 WIB.

Yunani, Achmad \& Djoko Mursinto. (2014). "Influence of Government Investment and Private Investment to Economic Growth, Manpower Absorption and Amount of Poor Population in Regencies/Cities in South Kalimantan Province in 20022012"Journal of Economics and Sustainable Development. www.iiste.org ISSN 2222-1700 (Paper) ISSN 2222-2855.

Zamrowi, M. Taufik. (2007).

"Analisis Penyerapan Tenaga Kerja Pada Industri Kecil (Studi di Industri Kecil Mebel Kota Semarang)". Tesis.
Program Pascasarjana Universitas Diponegoro. Semarang, Diakses 6 Nopember 2015 pukul 16.00 WIB. 